\title{
A Study on Prevalence of Trypanosomosis, its Risk Factors and Anaemia in Cattle of Damot Woyde District, Southern Ethiopia
}

\author{
Ephrem Takele*, Geja Gechere \\ Wolaita Sodo Tsetse Fly and Trypanosomosis Control Station, Ethiopia
}

*Corresponding Author: Ephrem Takele, Wolaita Sodo Tsetse Fly and Trypanosomosis Control Station, WolaitaSodo, Email: ephremtakele58@gmail.com

\begin{abstract}
A cross-sectional study was conducted from September, 2018 to October, 2018 in three purposively selected peasant associations (PAs) of DamotWoyde district of Southern Ethiopia to determine the prevalence of bovine trypanosomosis,to identify the prevailing species of trypanosomes, to assess potential risk factors and to evaluate the association of anaemia and bovine trypanosomosis. Blood samples were collected from 144 randomly selected cattle of the study PAs and evaluated through conventional parasitological methods. The overall trypanosomosis prevalence was found to be 2.08\% (95\% CI 0.43-5.96). Trypanosoma congolense was the only species detected in the area. The prevalence was equal in all study PAs which was $2.08 \%$. The study also revealed higher trypanosomosis prevalence in male (3.27\%), adult $(2.53 \%)$, poor body conditioned (6.89\%), and black colored (20\%) animals than female (1.2\%), young $(1.54 \%)$, medium (0\%) and good body conditioned (1.05\%), and white (0\%) and red (1.98\%) colored animals respectively. However, there was no statistically significant variation between the study PAs, sexes, age groups, body condition and hair coat color categories of animals $(P>0.05)$. The mean packed cell volume $(P C V)$ of infected animals $(20.66 \pm 1.15 \mathrm{SD})$ was significantly $(P<0.05)$ lower compared to noninfected animals (25.9 $\pm 4.04 \mathrm{SD})$. The overall prevalence of anemia was 30.56\% (95\%CI 23.15-38.77).All of parasitaemic animals are anaemic with significantly $(p<0.05)$ higher prevalence of anaemia in parasitaemic animals (100\%) than aparasitaemic ones (29.07\%). In conclusion, bovine trypanosomosis is economically important disease that affects the health as well as productivity of cattle in DamotWoyde district. Hence, integrated trypanosomosis control strategies should be implemented to improve livestock production in the area.
\end{abstract}

Keywords: Trypanosomosis, PCV, DamotWoyde, prevalence, anaemia

\section{INTRODUCTION}

Trypanosomosis is a parasitic disease caused by unicellular protozoan parasites of the genus trypanosoma and family trpanosomatidae. They multiply in blood stream, lymphatic vessels and tissue, including cardiac muscle and the central nervous system [1]. Trypanosomosis is transmitted by tsetse flies (Glossina species) and believed to be the most important infectious disease holding back development of livestock production in Africa [2]. Trypanosomosis is one of the major constraints on animal production in areas of Africa which have the greatest potential for significant increases in domestic livestock productivity [3]. Tsetse flies occur over some 10 million square kilometer of Africa [4] affecting a total of 38 countries. Currently, about $37 \%$ of the 147 million cattle in countries affected by tsetse are exposed to the disease. Africa produces 70 times less animal protein per unit area than Europe [5]. The disease in Africa costs livestock producers and consumers an estimated US\$1340 million each year [6]. In Ethiopia above 14 million heads of cattle are exposed to the risk of trypanosomosis, 20,000 heads of which die every year. Annual estimated losses for Ethiopia as a result of trypanosomosis is roughly US\$200 million, in terms of mortality and morbidity losses in livestock (excluding utilization of fertile land for crop and livestock production) and the costs included in controlling the disease. In the years 1978-1982 a total of 9,675,575 doses of trypanocidal drugs were purchased with 17,920,780.70 birr [7].

Although tsetse flies have existed in Ethiopia for a very long time, it has been noted that by early explorer, who lost their transport animals in the fly challenge belts. In 1885, Donald and Smith made the earliest record of Gendi (Nagana) in their transport animals which were crossing tsetse fly belts in southern Ethiopia [8]. Later in 1895 Corti identified an insect collected in 1893 
by Captain Bottogo, along the Walmal River which is the upper tributary of Shebelle River [9]. The infested area extends from the southern part of the Rift Valley, around the south-western corner of the country and along the western lowlands and escarpments to the Blue Nile [10]. In 1962, the cattle survey in southern Ethiopia by the livestock division, established that bovine trypanosomosis had become a major cattle disease in the Omo valley. It was stated that the problem of trypanosomosis is the main cause of decline in the number of cattle and particularly draught oxen [11]. Report from the tsetse infested area of Ethiopia indicated that $\mathrm{T}$. congolense is the most prevalent trypanosome species [11, 12].

The diseases which are caused by $\mathrm{T}$. congolenseand T.brucei.brucei are limited to southern and western areas of the country. Currently the livestock production and productivity of southern region is highly affected by the high incidence of the trypanosomosis. Therefore, taking in to an account the above-mentioned statements, the following objectives were designed to conduct studies:

- To determine the prevalence of bovine trypanosomosis on the basis of PA, sex, age, body condition, and color of animals.

- To determine the prevailingspecies of trypanosomes affecting cattle in the study area.

- To evaluate the association of anaemia and bovine trypanosomosis

\section{Materials AND MethodS}

\subsection{Description of the Study Area}

The study was conducted in Damot Woyde district of southern Ethiopia. Damot Woyde is located $335 \mathrm{~km}$ south of the capital, Addis Ababa. According to zonal statistical data, the district has 24 peasant associations and the total human population is 125441 ; the total cattle population is 61300 and population number per kilometer square is 300 people and the total area of the district is $352 \mathrm{~km}^{2}$. Damot Woyde district lies at 6049'59.99"N latitudes and 38000' 0.00" $\mathrm{E}$ longitudes. The altitude ranges from $1001 \mathrm{~m}$ to $2100 \mathrm{~m}$ above sea level. Moreover, the altitude of lowlands varies from 1001 to $1600 \mathrm{~m}$ above sea level. The district has two agro-ecological zones namely lowland (kola), and mid land (woynadega) of which the largest part is covered by mid land (woinadega) which accounts for $60 \%$ and the remaining $40 \%$ accounts for kola. The minimum and maximum average annual temperatures are $180 \mathrm{C}$ and $210 \mathrm{C}$ respectively. The total mean annual rain fall is $804.1 \mathrm{~mm}$ in lowland area to $1116.5 \mathrm{~mm}$ in midland (woinadega). The rainfall distribution is bimodal with highest fall at wet season (April to September) and lowest fall at last half of dry season (February to March). The prevailing production system in the area is mixed crop and livestock production. The vegetation of the study peasant associations (PAs) is dominantly occupied by woody grass land (WGL) and shrubs. The livestock population of the district is cattle $(70,908)$, sheep $(25,692)$, goats $(27,460)$, equines $(7,872)$ and poultry $(81,478)[13]$.

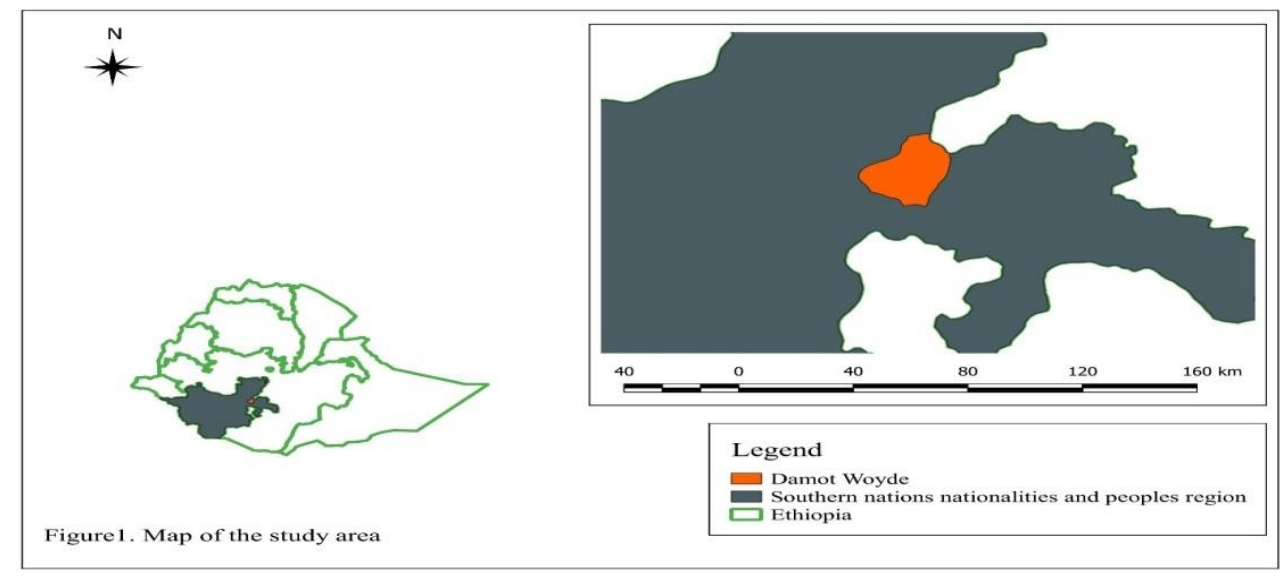

Figure1: Map of the study area

\subsection{Study Population}

The survey was conducted in three purposively selected PAs of Damot Woyde district namely, Elo Erasho, AnkaShashara, and Tora Sadebo.
The study involved 144 zebu cattle of different ages and both sexes owned by local farmers. The cattle were reared with the traditional extensive husbandry system. 


\subsection{Study Design}

A cross-sectional type of survey is conducted from September, 2018 to October, 2018 in the selected localities. Three peasant associations (PAs) were purposively selected due to higher tsetse density than other PAs.Blood samples were collected for examination of trypanosomosis and data regarding age, sex, body condition and color were collected at the time of sampling.The age was categorized into two groups:young ( $\leq 3$ years) and adult $(>3$ years old). The body condition score was grouped into good, medium and poor based on the appearance of ribs and dorsal spines applied for zebu cattle [14].

\subsection{Sample Size and Sampling Method}

The three peasant associations (PAs) were purposively selected due to higher tsetse challenge and animals from each PA were selected using systematic random sampling of every other animal caught at sample collection points. A 95\% confidence interval and 5\% absolute required precision and estimated or expected prevalence of $7.1 \%$ from previous study [15] in the area were used to determine the sample size for this particular study. The sample size was determined using the following formula [16].

$$
\mathrm{n}=1.96^{2} * \frac{\operatorname{Pexp}(1-\mathrm{Pexp})}{\mathrm{d}^{2}}
$$

$\mathrm{n}=$ required sample size

Pexp $=$ expected prevalence $=0.071$

$\mathrm{d}=$ desired absolute precision $=0.05$

Accordingly, the sample size was determined to be 101 . However, a total of 144 samples were collected to increase the accuracy of the study.

\subsection{Parasitological and Hematological Techniques}

The parasitological diagnostic tests used were those described by [17]. In brief, blood was aseptically collected from peripheral ear vein into heparinized capillary tubes. Each capillary tube was filled to its last third and sealed with crystal seal at one end and centrifuged immediately in a micro heamatocrit centrifuge for five minutes at 12000rpm. After centrifugation, the packed cell volume (PCV) was determined. Animals with PCV less than or equal to $24 \%$ were considered to be anaemic [18]. The capillary tube was cut using a diamond tipped pen $1 \mathrm{~mm}$ below the buffy coat to include the upper most layers of the red blood cells. The extracted samples were placed on to microscopic slide and examined under phase contrast microscope with a $40 \mathrm{x}$ objective for the presence of motile trypanosomes.

\section{Data Analysis}

The collected raw data and the results of parasitological and hematological examination were entered into a Microsoft excel spread sheets. The data were analyzed using STATA ${ }^{\circledR}$ (version 14.0) software program from STATA Corporation, College Station, Texas. The prevalence of trypanosome infection was calculated as the number of positive animals as examined by buffy coat methoddivided by the total number of animals examined at that particular time. The association between trypanosomosis infection status and different risk factors were assessed using univariable binomial logistic regression. Mean PCV of parasitaemic and aparasitemic cattle were compared by using two sample student ttest.Moreover, the association between anaemia andtrypanosomosis prevalence was analyzed using Pearson chi-square test. Differences between parameters were tested for significance at probability level of $\mathrm{p}<0.05$ and $95 \%$ confidence interval.

\section{Results}

\subsection{Parasitological Findings}

Out of 144 examined cattle, 3 were positive for trypanosomosis and the overall prevalence of $2.08 \%$ (95\% CI 0.43-5.96) was registered. All parasitaemic animals were found to be infected by $T$. congolense.

\subsection{Risk Factor Analysis}

The prevalence of trypanosomosis was found to be equal in all study PAs which was $2.08 \%$. Moreover, trypanosomosis prevalence was higher in animals with poor body condition score $(6.89 \%$; $95 \% \mathrm{CI}=0.84-22.76)$ than in animals with medium body condition $(0 \% ; 95 \%$ $\mathrm{CI}=0-16.84)$ and good body condition scores $(1.05 \%$; $95 \% \mathrm{CI}=0.02-5.7)$. The prevalence of trypanosomosis in adult animals (>3years) $(2.53 \%$; $95 \% \mathrm{CI}=0.3-8.84)$ was higher than that of Young animals ( $\leq 3$ years) three years of age $(1.54 \%$; $95 \%$ CI 0.039-8.27). Higher prevalence of trypanosomosis was observed in male animals $(3.27 \%$; 95\% CI $=0.39-11.34)$ compared to female animals $(1.2 \%$; $95 \% \mathrm{CI}=$ 0.03-6.53). It was also observed that the 
A Study on Prevalence of Trypanosomosis, its Risk Factors and Anaemia in Cattle of Damot Woyde District, Southern Ethiopia

prevalence of trypanosomosis infection was higher in black hair coat colored animals (20\%; $95 \mathrm{CI}=0.5-71.64)$ than white $(0 \%$; $95 \%$ CI 0 9.25) and red hair coat colored ones $(1.98 \%$; 95\% CI 0.24-6.97) (Table1). However, there

Table1: Logistic regression analysis of the prevalence of trypanosomosis with hypothesized risk factors

\begin{tabular}{|c|c|c|c|c|c|c|c|}
\hline $\begin{array}{l}\text { Risk } \\
\text { factors }\end{array}$ & Category & $\begin{array}{l}\text { No } \\
\text { Examined }\end{array}$ & $\begin{array}{l}\text { No } \\
\text { Positive }\end{array}$ & $\begin{array}{l}\text { Prevalence } \\
(\%)\end{array}$ & {$\left[\begin{array}{lll}95 \% & \mathrm{CI}\end{array}\right.$} & $\begin{array}{l}\text { OR } \\
{\left[\begin{array}{ll}95 \% & C I\end{array}\right]}\end{array}$ & $\begin{array}{l}\mathbf{P} \\
\text { value }\end{array}$ \\
\hline \multirow{3}{*}{ PA } & Elo Erasho & 48 & 1 & 2.08 & $0.05-11.07$ & Reference & - \\
\hline & AnkaShashara & 48 & 1 & 2.08 & $0.05-11.07$ & $0.48[0.04-5.58]$ & 0.56 \\
\hline & Tora Sadebo & 48 & 1 & 2.08 & $0.05-11.07$ & $0.48[0.04-5.58]$ & 0.56 \\
\hline \multirow[t]{2}{*}{ Sex } & Male & 61 & 2 & 3.27 & $0.39-11.34$ & \multirow[t]{2}{*}{$0.36[0.03-4.06]$} & \multirow[t]{2}{*}{0.4} \\
\hline & Female & 83 & 1 & 1.2 & $0.03-6.53$ & & \\
\hline \multirow[t]{2}{*}{ Age } & $\leq 3 \mathrm{yrs}$ & 65 & 1 & 1.54 & $0.039-8.27$ & \multirow[t]{2}{*}{$1.66[0.15-18.75]$} & \multirow[t]{2}{*}{0.68} \\
\hline & $>3 \mathrm{yrs}$ & 79 & 2 & 2.53 & $0.3-8.84$ & & \\
\hline \multirow[t]{3}{*}{$\overline{B C S}$} & Poor & 29 & 2 & 6.89 & $0.84-22.76$ & Reference & - \\
\hline & Medium & 20 & 0 & 0 & $0-16.84$ & 1 & - \\
\hline & Good & 95 & 1 & 1.05 & $0.02-5.7$ & $0.14[0.01-1.64]$ & 0.11 \\
\hline \multirow[t]{3}{*}{ Color } & White & 38 & 0 & 0 & $0-9.25$ & 1 & \\
\hline & Red & 101 & 2 & 1.98 & $0.24-6.97$ & $0.08[0.006-1.08]$ & 0.058 \\
\hline & Black & 5 & 1 & 20 & $0.5-71.64$ & Reference & \\
\hline
\end{tabular}

$B C S=$ Body Condition Score $; C I=$ Confidence Interval; $O R=$ Odds Ratio $; P A=$ Peasant Association

\subsection{Hematological Examination}

The overall mean PCV in the examined animals was 19.52 $\pm 4.87 \mathrm{SD}$. Packed cell volume of parasitemic animals ranges from $20-22 \%$, while in aparasitemic cattle the PCV was in the range of $14-36 \%$ (Figure 2). The mean PCV of parasitaemic animals is $20.66 \pm 1.15 \mathrm{SD}$ which is was no statistically significant association between the different PAs, body condition categories, age groups, sexes and hair coat color of animals $(p>0.05)$.

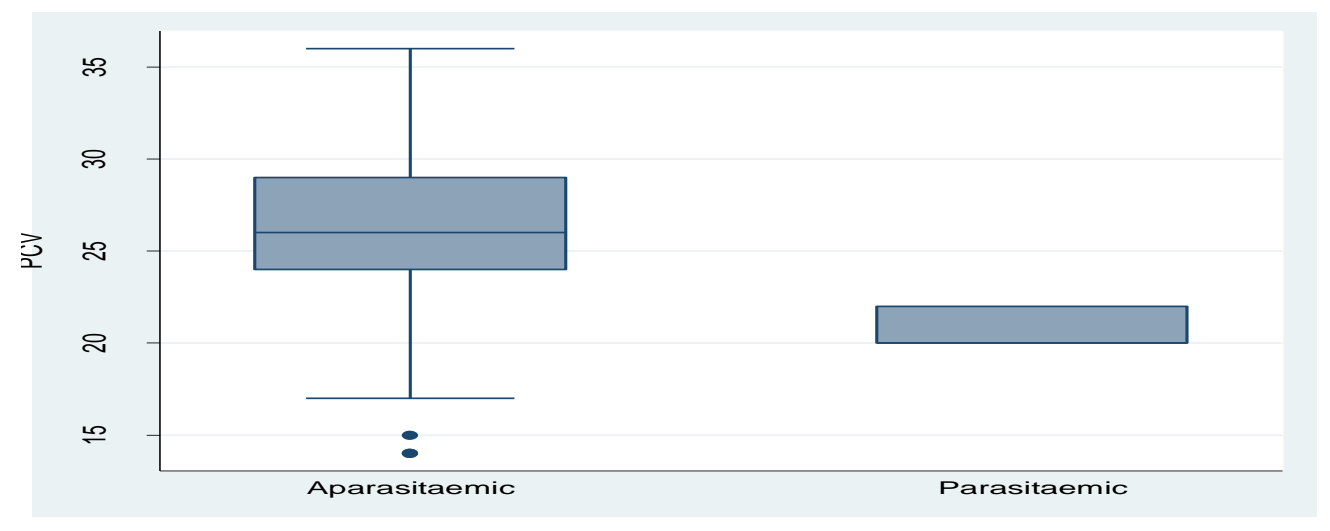

Figure2: Overall Mean PCV of aparsitaemic and parsitaemic animals

From the total of 144 cattle examined, $30.56 \%$ $(44 / 144)$ were anemic with mean PCV of $21.11 \%$ (95\% CI 20.28-21.94) while $69.44 \%$ $(100 / 144)$ were non-anaemic and their mean PCV was 27.86 (95\% CI 27.34-28.37) (Table 3). The overall anaemia prevalence was found to be $30.56 \%$ ((95\%CI 23.15-38.77). Comparison of trypanosomosis prevalence betweenanaemicand non-anaemicanimals revealed thatout of 44 anaemic animals, $3(6.81 \%)$ were parasitaemic while, none $(0 \%)$ of non-anaemic animals are parasitaemic. The proportion of parasitaemic lower than the lower limit of normal PCV for cattle. The mean PCV for aparasitaemic animals, is $25.9 \pm 4.04 \mathrm{SD}$ and falls within a normal PCV value range (Table2). There was a statistically significant difference in the mean PCV between the infected and non-infected animals $(\mathrm{p}<0.05)$. animals among the anemic ones $(6.81 \%)$ was significantly higher compared to the proportion of parasitemic animals among the non-anemic ones $(0 \%)(\mathrm{P}<0.05)$ (Table 3$)$

Furthermore, comparison of anaemia prevalence between parasitaemic and aparasitaemic animals revealed that all parasitaemic animals $(100 \%)$ are anaemic; while among the 141 aparasitaemic animals, 41 (29.07\%) were anaemic with PCV value $\leq 24$. The proportion of anemic animals among the parasitaemic ones (100\%) was significantly higher compared to the proportion 
A Study on Prevalence of Trypanosomosis, its Risk Factors and Anaemia in Cattle of Damot Woyde District, Southern Ethiopia

of anemic animals among the aparasitemic ones

$(29.07 \%)(\mathrm{P}<0.05)($ Table 4).

Table2: Mean PCV of parasitaemic and aparasitaemic animals

\begin{tabular}{|c|c|c|c|c|c|c|}
\hline Infection status & No examined & Mean PCV \pm SD & $95 \% \mathrm{CI}$ & SE & t-test & $P$ value \\
\hline Aparasitaemic & 141 & $25.9 \pm 4.04$ & $25.23-26.58$ & 0.34 & \multirow[t]{3}{*}{2.27} & \multirow[t]{3}{*}{0.027} \\
\hline Parasitaemic & 3 & $20.66 \pm 1.15$ & $17.79-23.53$ & 0.66 & & \\
\hline Overall & 144 & $25.79 \pm 4.07$ & $25.13-26.47$ & 0.34 & & \\
\hline
\end{tabular}

$P C V=$ Packed Cell Volume; SD = Standard Deviation; $C I=$ Confidence Interva lSE = Standard Error

Table3: Comparison of trypanosomosis infection between anaemic and non-anaemic cattle

\begin{tabular}{|l|l|l|l|l|l|l|}
\hline Category & $\begin{array}{l}\text { No } \\
\text { examined }\end{array}$ & $\begin{array}{l}\text { No } \\
\text { positives }\end{array}$ & $\begin{array}{l}\text { Proportion of } \\
\text { Positives [95\% CI] }\end{array}$ & Mean PCV [95\% CI] & \multirow{2}{*}{$\begin{array}{l}\mathbf{P} \\
\text { value }\end{array}$} \\
\cline { 1 - 5 } Anaemic & 44 & 3 & $6.81[1.43-18.65]$ & $21.11[20.28-21.94]$ & \multirow{2}{*}{6.96} & 0.008 \\
\cline { 1 - 4 } Non-anaemic & 100 & 0 & $0[0-3.62]$ & $27.86[27.34-28.37]$ & & \\
\cline { 1 - 5 } Overall & 144 & 3 & $2.08[0.43-5.96]$ & $25.79[25.13-26.47]$ & & \\
\hline
\end{tabular}

$P C V=$ Packed Cell Volume $; S D=$ Standard Deviation $; C I=$ Confidence Interval

Table4: Comparison of anaemia prevalence between parasitaemic and aparasitaemic cattle

\begin{tabular}{|l|l|l|l|l|l|}
\hline $\begin{array}{l}\text { Infection } \\
\text { status }\end{array}$ & $\begin{array}{l}\text { No } \\
\text { animals }\end{array}$ & $\begin{array}{l}\text { No of anaemic } \\
\text { animals }\end{array}$ & $\begin{array}{l}\text { Proportion of anaemic } \\
\text { Animals (\%) }\end{array}$ & $\boldsymbol{\chi} \mathbf{2}$ & P value \\
\hline Parasitaemic & 3 & 3 & 100 & 6.96 & 0.008 \\
\cline { 1 - 2 } & 141 & 41 & 29.07 & & \\
\hline Overall & 144 & 44 & 30.56 & \\
\cline { 1 - 3 }
\end{tabular}

\section{DISCUSSION}

During the present study, an overall prevalence of $2.08 \%$ (95\% CI $0.43-5.96)$ resulted. The result of the present study was similar to findings of [19] which found an overall prevalence of $2.86 \%$ in Dale Wabera district of KelemWollega zone; [20] which found $2.1 \%$ in Amhara region northwest Ethiopia; and [21] which found $2.3 \%$ in Morogoro district of Tanzania. However, this finding was considerably lower than the reports of $[15,22$, 23,24 and 25] who reported $7.3 \%, 14.2 \%$, $15.8 \%, 21.0 \%$ and $35.5 \%$ prevalence of bovine trypanosomosis respectively at DamotWoyde, Humbo, Omo river basin, and KindoKoyshaof South Western Ethiopia. The lower report in the current study could be attributed to concerted efforts of tsetse suppression and trypanosomosis control by Wolaita Sodotsetse fly and trypanosomosiscontrol station, disturbance of tsetse ecology due to expansion of cultivation in the area which significantly reduced tsetse population in the study area. All of trypanosome positive animals were found to be infected with Trypanosoma congolense. The higher proportion of Trypanosoma congolensein the study area is in agreement with findings of [22, 19, 26 and 15]. The predominance of T.congolense in the study suggests that glossina species are more efficient transmitters of Trypanosoma congolensethan T.vivax in East Africa [9] and also due to the high number of serodems of T.congolense as compared to
T.vivax and the development of better immune response to T.vivax by infected animals [12].

The prevalence of trypanosomosis was equal in all study PAs with no significant difference between the study PAs ( $p>0.05$ ). This might be due to the geographical location of the three kebeles in the same climatic zones. This result is in conformity with findings obtained by [27] at Soddo Zuria Woreda, [22] in Humbo district, and [26] in Konta special district.

In the present study, body condition has shown to have significant effect on prevalence of trypanosome infection $(\mathrm{p}<0.05)$ with higher prevalence recorded $(6.89 \%)$ in animals with poor body condition. Animals with poor body condition score were more associated with disease compared to animals with medium and good body condition. This is in line with [15, 28, 29 and 30].

Obviously, the disease itself results in progressive emaciation of the infected animals; nevertheless, non-infected animals under good body condition have well developed immune status that can respond to any foreign protein better than those of non-infected cattle with poor body condition score which can be immunocompromised due to other diseases or malnutrition and concurrent infections depress the immune responsiveness in the same cases [31]. In the present study, age was considered to be one of the risk factors for trypanosome infection. Accordingly, there was no statistically 
significant difference among different age groups $(\mathrm{P}<0.05)$. However, higher infection rate was observed in adult animals $(2.53 \%)$ and young animals $(1.54 \%)$ in the study area. This result is in conformity with findings of $[22,32$, and 20]. The possible reason for this is assumed to be that older animals travel long distance for grazing and provide draught power as well as harvest crops in tsetse challenge areas.

The prevalence of trypanosomosis was slightly higher in male animals (3.27\%) than the female ones $(1.2 \%)$ though it was not statistically significant $(\mathrm{p}>0.05)$. This result is similar with the report of $[19,15,33$, and 32]. But the present finding is different from the report by $[22,29$, and 34] who revealed the prevalence of trypanosomosis was higher in female cattle in Humbo, Mao-komo, and Yayo districts respectively. The possible reason for this higher prevalence could be that male animals are obliged to provide draught power for ploughing, travel long distance in the areas where there is tsetse challenge and consequently the risk of contracting trypanosomosis is higher in males. The prevalence of trypanosomosis is compared between different hair coat colors of cattle; accordingly, higher prevalence was observed in animals having black hair coat color (20\%) followed by $1.98 \%$ in red hair coat color, and no prevalence was recorded in white hair coat colored ones.

This result is in agreement with the results of [15, 22 and 26]. The proposed reason for this is may be due to the fact that tsetse flies are naturally attracted toward a black color, so in animals having black hair coat color, high prevalence of trypanosomosis is recorded [35]. This result in line with the report at wolaita zone by [15] who reported the prevalence in black $(14.3 \%)$, red $(8.3 \%)$ and white $(2.5 \%)$ hair coat animals. Out of the 144 observed animals, 3 $(2.08 \%)$ of them were positive for trypanosomosis and their mean PCV value was $20.66 \pm 1.15$ SD. There was a significant difference between mean PCV of parasitaemic and aparasitaemic cattle $(\mathrm{p}<0.05)$. The remaining 141 animals were aparasitaemic with a mean PCV value of $25.9 \pm 4.04 \mathrm{SD}$. This result is in agreement with [37] who observed that an increase in PCV value will result in decrease in proportions of positivity and hence mean PCV was a good indicator for the health status of animals in an endemic area. The lower mean PCV in parasitemic animals than the aparasitemic animals was reported by several authors $[38,39$,
40, and 41]. Out of 144 cattle examined, 44 were anemic with mean PCV of $21.11 \%$ and the overall anaemia prevalence was $30.56 \%$.

This finding is higher than the previous study by [32 and 42] which found $19.27 \%$ and $19.67 \%$ at Dale Wabera and Yayodistricts respectively. However, it is lower than the finding of [43] which found anaemia prevalence of $41 \%$ at Arbaminch. The proportion of parasitaemic animals among the anemic ones $(6.81 \%)$ was significantly higher compared to the proportion of parasitemic animals among the non-anemic ones $(0 \%)(\mathrm{P}<0.05)$. Moreover, all $(100 \%)$ of parasitaemic animals were anaemic and the proportion of anemic animals among the parasitaemic ones (100\%) was significantly $(\mathrm{P}<0.05)$ higher than the proportion of anemic animals among the aparasitemic ones (29.07\%). Similar results were reported by [43] at Arbaminch (85\%) and [44] at Gidami district (92.3\% in early dry and $91.3 \%$ in early rainy seasons).

This is attributed to the fact that anaemia is useful indicator of trypanosomosisinfection in endemic areas [18]. The study also indicated that $29.07 \%$ (41/141) of aparasitaemic animals are anaemic with $\mathrm{PCV} \leq 24$. The possible reason for this could be lower accuracy of PCV detection method, prolonged period of recovery from anaemia following recent trypanocidal chemotherapy. Although anaemia is characteristic of trypanosomosis, other factors are also anticipated to affect the PCV profile of animals. Diseases such as gastrointestinal parasitism, vector-borne diseases and nutritional deficiencies can also cause reduced PCV [45].

\section{Conclusion}

In the present study, it was observed that the prevalence of trypanosomosis is significantly lower than before due to consistent implementation of tsetse fly and trypanosomosis control by WolaitaSodotsetse fly and trypanosomosis control station. Overall trypanosomosis prevalence of $2.08 \%$ was recorded. The study also indicated that the dominant trypanosome species in the study area was $T$. congolense. The host risk factors analysis of the study showed higher prevalence in males than females; in adult cattle than in younger ones; and in animals with poor body condition score. No significant variation between different PAs, age, sex, and body condition and color of animals was observed. The mean PCV of aparasitemic animals was 
higher than parasitemic animals. Anaemia was typical manifestation of trypanosomosis infection. Therefore, further integrated control approaches particularly ground suppression, deployment of insecticide impregnated targets and application of adequate pour-on insecticide on vulnerable cattle needs to be implemented to significantly lower the prevalence. Moreover, further studies should be conducted in different seasons to know apparent density of tsetse flies as well as to observe seasonal dynamics of trypanosomosis prevalence in the area.

\section{REFERENCES}

[1] Soulsby, E.J.L (1992): Helminthes, Arthropods and protozoa of Domestic Animals. 7th Ed. Buillier, Tindall, pp. 422-423.

[2] Itard J (1981): African animal trypanosomosis. In manual of veterinary Parasitology. Pp.179-2 91.

[3] D'Ieteren,G.D.M., Authie, E., Wissoqeo, N., Murry, M ((1998): Trypanotolerance an option for sustainable livestock production in areas at risk from trypanosomosis OIE scientific and Technical review. Pp 154-175.

[4] Jordan A.M (1986): Trypanosomosis control and Africa Rural Development, New York: Longman group.

[5] [5]Nntulya V.M (1986): Immunological approaches to the control of animal Trypanosomosis: Trop. Med parasite.140, 168-173.

[6] Ayisheshim A, Abegaz S, Derso S, Shewatatek M, Hailemariam H, Shiret B, Natnael M (2015). Review on Bovine Trypanosomosis in Ethiopia, European J. Biol. Sci. 8(1):01-07.

[7] MoA(1982/823):Annual report of trypanosomosis control service.Addis Ababa, Ethioipia.

[8] Mc Lennan K.J.R (1980): Tsetse transmitted Trypanosomosis in relation to rural economy in Africa. Part I. Tsetse infestation, World Animal Rev. 37, 9-18.

[9] Langridge W.P (1976): A tsetse and trypanosomosis survey of Ethiopia. Ministry of overseas Development, UK and Ministry of Agriculture of Ethiopia. Pp 1-98.

[10] Bezabih M, Shabula Z, Beyene N (2015). Prevalence of bovine trypanosomiasis in Dara District Sidama Zone, Southern Ethiopia. J. Parasitol. Vector Biol. 9(9):132-136

[11] Abebe, G. And Jobre, Y. (1996): Trypanosomosis: A threat to cattle production to Ethiopia. Rev. Med. Vet 147, 897 -902.

[12] Rowlands GJ., Mulatu W., Authie E., Leak S.G.A, D'Iteren G.D.M, Naga SM, Peregrine AS (1993): Epidemiology of bovine trypanosomosis in the Ghibe valley, southwest Ethiopia. 2. Factors associated with variations in trypanosome prevalence, incidence of new infections and prevalence of recurrent infections. Acta Trop. 1993 Apr; 53(2):135-50.

[13] WZSEP (2010): Wolaita Zone Socio-economic Profile. WolaitaSoddo, Ethiopia.

[14] Nicholson MJ and Butterworth MH (1986): A guide to body condition scoring of zebu cattle. ILCA, Addis Ababa Ethiopia. pp. 212-235.

[15] Gona, Z, Teshale, A, Tilahun, A (2016): Study on prevalence of bovine trypanosomosis and density of its vectors in three selected districts of Wolaita Zone, Southern Ethiopia. Academic J. Vol. 8(9): 128-135.

[16] Thrusfield, M. (2005): Veterinary epidemiology. 3rd ed. Black well science Ltd., Oxford, Great Britain. Pp. 182-198.

[17] Murray, M. Murray, P. K. and Mcintyre, W. I. M., 1977. An approved parasitological technique for the diagnosis of African animal trypanosomosis. Trans. R. Soc. Trop. Med. Hyg., 71, 325-326.

[18] [18] RadostitisO.M, Gay C.C, and Hinchcliff K.W and Constable P.D (2007): Veterinary medicine.A text book of the disease of Cattle, Sheep, Pigs, Goats and Horses.10th ed. W.B. Saunders Ltd. Pp 1395-1412.

[19] Biyazen H, Duguma R, Asaye M (2014): Trypanosomosis: Its risk factors and anaemia in cattle population of Dale Wabera district of KelemWolega Zone, Western Ethiopia. J.Vet Med: 2014: 374191.

[20] Ayana M, Tesfaheywet Z, Getnet F (2012): A cross-sectional study on the prevalence of bovine trypanosomosis in Amhara region, Northwest Ethiopia. Journal Livestock Research for Rural Development: 24(8).

[21] Nonga H.E and Kambarage D.M (2009): Prevalence of trypanosomiasis in Morogoro, Tanzania Palestinian Journal of Nutrition Vol. 8(3): 208-2013.

[22] Feyisa B, Samson A, Mihreteab B (2011). Bovine Trypanosomosis in Selected Villages of Humbo District, Southern Ethiopia. Glob. Vet. 7(2):192-198.

[23] [23] TerzuD (2004): Seasonal dynamics of tsetse and trypanosomosis in selected sites of SNNPRS, Ethiopia. MSc thesis, Addis Ababa University Faculty of Veterinary Medicine, Debrezeit.

[24] AmareB (1995): Preliminary survey on tsetse distribution and prevalence of Bovine trypanosomosis in selected woredas of NorthOmo and KAT zones. DVM thesis, Addis Ababa University, Faculty of Veterinary Medicine, Debrezeit.

[25] Mesfin A and Getachew A (2001): Field studies on drug resistant trypanosome of cattle (Bos indicus) in kindoKoysha woreda, southern 
Ethiopia. Bull. Anim. Health Prod. Afr. 48:131-138.

[26] Abera A, Sibhat B, Tonamo A (2015): A study on the prevalence of bovine trypanosomosis in selected areas of Konta Special Woreda, Southern Ethiopia. Academic Journals: 11(6) 500-506.

[27] Getnet B (2008): Prevalence of bovine trypanosomosis in SoddoZuriaWereda, SNNPRS. DVM thesis. Haramaya University, Ethiopia.

[28] Habtwolde T (1995): Community based tsetse and trypanosomosis control pilot programme using Deltamethrin in Konso, Southern Ethiopia. Proceeding of 11th Conference of the Ethiopia Veterinary Association, Addis Ababa, Ethiopia. pp. 57-65.

[29] Dawud A and MolalegnB (2011): Epidemiological study of Bovine Trypanosmosis in Mao-komo Special District, Benishangul Gumuz Regional State, Western Ethiopia. Global Veterinaria, 6: 402-408.

[30] Abiy M (2002): Prevalence of bovine trypanosomosis in Goro woreda, southwest Ethiopia. DVM Thesis FVM, AAU, Debrezeit, Ethiopia. Pp 18.

[31] CollinsFM (1994): The immune response to mycobacterium infection, development of new vaccine. Vet. Microbiol. 40:95-110

[32] Yigzaw B, Asmare T,Dereso S (2017): Prevalence of bovine trypanosomosis and its vector density in in Sheka Zone, Andericha woreda. Online Journal of animal and feed research 7(3): 51-57.

[33] Mulatu A, Lelisa K, Damena D (2016): Prevalence of bovine trypanosomosis and apparent density of Tsetse flies in eastern part of Dangur District, Northwestern Ethiopia.J. Vet Sci Technol 7:347

[34] KitilaG, Kebede B, Guta D, Bekele F, Wagari M, Tilahun B, Jaleta D (2016):Epidemiological Investigation of Bovine Trypanosomosis and its Vector Apparent Densities in Yayo District Illuababora Zone, Western Oromia, Ethiopia. Research and Reviews: Journal of Veterinary Science pp. 10-15.

[35] Teka W, Terefe D, Wondimu A (2012): Prevalence study of bovine trypanosomosis and tsetse density in selected villages of Arbaminch, Ethiopia. J. Vet. Med. Anim. Health 4(3):36-41.
[36] Haile C (1996): Bovine trypanosomosis in North Oromo, prevalence and assessment of drug efficacy DVM Thesis Addis Ababa University, Debre Zeit, Ethiopia.

[37] Rowlands GS,Mulatu W,Authie E, Leak SGA, Peregrine A (1999): Epidemiology of bovine Trypanosomosis in the Ghibe valley, South West Ethiopia. Acta Trop. 53:135-150.

[38] Leak SGA (1999): Tsetse Biology and Ecology: Their role in the Epidemiology and control of Trypanosomosis. Wallingford, Oxon, UK: CABI publishing. pp. 152-210.

[39] Afework Y (1998): Field investigations on the appearance of drug resistant population of trypanosome in Metekel district, Northwest Ethiopia. MSc Thesis, AAU with Frey University, Berlin.

[40] Muturi KS (1999): Epidemiology of Bovine Trypanosomosis in selected sites of the Southern Rift Valley of Ethiopia. MSc Thesis, FVM, AAU, Ethiopia.

[41] Tewolde N (2001): Study on the occurrence of resistant trypanosomes in cattle in the farming in tsetse control areas (FITCA) project in western Ethiopia MSc thesis, Addis Ababa University and FreieUniverstat, Berlin.

[42] Haile G, Mekonnen N, Lelisa K, Habtamu Y (2016). Vector identification, prevalence and anemia of bovine trypanosomosis in Yayo District, Illubabor Zoneof Oromia Regional State, Ethiopia. Ethiopian Veterinary Journal 20(1):39-54.

[43] Zecharias, A and Zeryehun, T (2012): Prevalence of bovine trypanosomosis in selected district of Arba Minch, SNNPR, Southern Ethiopia. Global Vet., 8(2), 168-173.

[44] Degneh E, Shibeshi W, Terefe G Asres K, Ashenafi H (2017): Bovine trypanosomosis: Changes in parasitaemia and packed cell volume in dry and wet seasons at Gidami district, Oromia Regional State, western Ethiopia. ActaVetScand (2017) 59:59. DOI 10.1186/s13028-017-0327-7.

[45] Van den Bossche P and RowlandsG.J (2001): The relationship between the parasitological prevalence of trypanosome infections in cattle and herd average packed cell volume. Acta Tropica. 2001; 78(2):163-170.

Citation: Ephrem Takele, A Study on Prevalence of Trypanosomosis, its Risk Factors and Anaemia in Cattle of Damot Woyde District, Southern Ethiopia, ARC Journal of Animal and Veterinary Sciences. 2019; 5(4):1-8. doi: dx.doi.org/10.20431/2455-2518.0504001.

Copyright: (C) 2019 Authors. This is an open-access article distributed under the terms of the Creative Commons Attribution License, which permits unrestricted use, distribution, and reproduction in any medium, provided the original author and source are credited. 